\title{
Peran Religiusitas Mengatasi Kecemasan Masa Menopause
}

\author{
Meithya Rose Prasetya*, Masni Erika Firmiana, Rochimah Imawati \\ Program Studi Psikologi, Fakultas Psikologi dan Pendidikan \\ Universitas Al Azhar Indonesia, Jl. Sisingamangaraja, Jakarta, 12110 \\ *Penulis untuk Korespondensi: meithyaprasetya@gmail.com
}

\begin{abstract}
Abstrak - Masa menopause adalah hal yang alamiah dan tidak terelakkan pada setiap perempuan yang memasuki usia 50. Di saat memasuki masa menopause, perempuan mengalami perubahan penting dalam kehidupannya. Ini tidak hanya terjadi pada sisi fisiologis, tetapi juga kehidupan psikologis dan sosial perempuan. Memang perubahan ini tidak dialami perempuan secara universal, tetapi banyak penelitian mencatat bahwa menopause akan membawa pengaruh yang besar dalam perubahan fungsi tubuh, produksi hormon, status reproduksi, hubungan, penampilan, ekspektasi, dan kondisi sosial (Stewart, 2005). Penelitian ini berusaha untuk melihat bagaimana perempuan dalam usia pramenopause dan pasca menopause mengenali, menghadapi dan mensikapi pada saat proses menopause dan setelah menopause. Penelitian menemukan variabel-variabel yang mempengaruhi perempuan dalam mempersepsikan dan menghadapi menopause.
\end{abstract}

Abstract - The menopause has been described as a deficiency disease associated with a wide variety of physical and psychological symptoms. In our study, we purposed to investigated whether there is increase in perception and anxiety of body images in among postmenopause women. In conclusion, our study provides further insight into the positive association between religiosity in perception and acceptance of menopause as a part of women life.

Keywords - perception, body image, menopause

\section{PENDAHULUAN}

\subsection{Latar Belakang}

Kecantikan telah menjadi hal esensial Ikehidupan perempuan dan tidak lepas dari konsep tentang "kecantikan ideal" yang berlaku umum, di mana "cantik secara ideal" lebih banyak dipahami secara ragawi, bertubuh langsing, berkulit kencang, dan selalu tampak muda (kalyanamitra. multiply.com).

Dalam kedokteran dijelaskan seiring pertambahan usia, fisik perempuan mengalami perubahan, utamanya ketika ia memasuki masa menopause, dibarengi penurunan produksi hormon (estrogen, progesteron, androstenedione, dan testoteren), berdampak pada kulit yang kendur dan keriput, berat tubuh naik, serta tulang akan mudah keropos. Selain itu, aktivitas seksual akan terganggu karena vagina yang kering akibat berkurangnya produksi estrogen secara drastis (Stewart, 2005:18-21). Ini membuat menopause diasoasikan dengan penuaan (aging) dan dianggap "bencana" oleh sebagian perempuan.

Beberapa pakar psikologi (mis. A. Kasandra Poetranto, dan beberapa hasil penelitian lain, mis. Dillaway, 2005; Ehrenreich \& English, 1973 dalam Berger, 1998:7) menunjukkan banyak perempuan yang masih memandang menopause sebagai pengalaman negatif. Citra negatif menopause semakin bertambah di tahun 1900an, di mana komunitas medis dunia Barat pada waktu itu memberikan gambaran menyedihkan tentang disposisi, emosi dan kestabilan mental dari perempuan yang menopause (Furman, 1995).

Lebih lanjut lagi, Dillaway (2005) dalam penelitiannya menemukan bahwa ada hubungan antara menopause dan citra tubuh. Sekitar 52 atau 85\% partisipan penelitian memandang menopause sebagai penyebab utama perubahan pada tubuh 
mereka. Bahkan Dillaway mengungkapkan, para partisipannya melihat menopause sebagai masalah karena membuat mereka sulit mempertahankan tubuh ideal. Namun demikian, Dillaway (2005) menegaskan, persepsi terhadap menopause dan citra tubuh merupakan hasil dari konstruksi sosial. Citra tubuh adalah persepsi, sikap dan perilaku individu terhadap tubuhnya (Banfield dan McCabe, 2002, dalam Davison dan McCabe, 2005). Banyak penelitian temukan bahwa tubuh yang ideal bervariasi di setiap budaya dan waktu. Di suku Hima, Uganda, perempuan bertubuh gemuk adalah cantik. Sebaliknya, budaya Barat kontemporer idolakan tubuh yang kurus bagi kaum perempuan dan tubuh sedang bagi laki-laki. Ini berbeda dengan kondisi di tahun 1950 ketika tubuh yang "montok" (full-figured) dianggap paling ideal, sementara di tahun 1990an justru tubuh yang bugar dirasa lebih menarik (Jackson dalam Cash \& Pruzinsky, 2002). Di Indonesia, parameter kecantikan ideal berbeda di setiap masa dan di berbagai suku. Pada abad ke18 , perempuan yang cantik adalah mereka yang memiliki tubuh berisi, sedangkan pada abad 21, tubuh langsing-lah yang dipandang cantik (Iswardani dalam Kartika, 2007). Konstruksi sosial terhadap menopause dan citra tubuh perempuan menopause inilah yang menjadi fokus dalam penelitian. Peneliti berupaya menggali persepsi perempuan pramenopause dan usia menopause terhadap menopause. Untuk partisipan usia pramenopause, peneliti lebih menggali persepsi mereka terhadap menopause dan citra tubuh mereka, sementara untuk partisipan usia menopause, lebih menekankan pada bagaimana citra tubuh mereka setelah mengalami menopause, selain persepsi mereka tentang menopause itu sendiri, terutama setelah dialami. Diharapkan, hasil penelitian ini dapat memberikan informasi yang mendalam mengenai bagaimana pandangan terhadap menopause dan tubuh menopause para subyek dikonstruksikan secara sosial.

\subsection{Pembatasan dan Perumusan Masalah Penelitian}

Berbagai fakta diatas mengenai menopause mendorong peneliti untuk mengangkat menopause sebagai fokus dalam penelitian ini. Penelitian ini akan mengangkat masalah:

1) Bagaimana persepsi menopause pada perempuan di usia pramenopause dan menopause?

2) Bagaimana gambaran citra tubuh yang telah menopause, baik dari persepsi dari perempuan yang belum mengalami menopause dan telah mengalami menopause?
3) Apakah ada hubungan antara persepsi terhadap menopause dan citra tubuh menopause?

\subsection{Pembatasan Masalah}

Penelitian ini membatasi pada hal:

1) Pandangan perempuan terhadap menopause dan pengaruhnya terhadap citra-tubuhnya

2) Konteks sosial-budaya yang membentuk pengalaman menopause dan citra-tubuh perempuan.

\section{KERANGKA TEORI/TINJAUAN PUSTAKA}

\subsection{Menopause}

Menopause adalah masa pada kehidupan seorang perempuan ketika kemampuan reproduksinya berhenti. Dalam hal ini, ovarium (sel telur) berhenti berfungsi dan produksi hormon steroid serta hormon peptida berhenti. Sebagai akibatnya, berbagai perubahan terjadi pada sistem organ tubuh perempuan (WHO, 1996). The Journalist's Menopause Handbook (2006) yang dikeluarkan oleh The Society of Obstetricians and Gynaecologists of Canada (SOGC) mendefinisikan menopause sebagai masa ketika seorang perempuan tidak lagi mengalami menstruasi. Meski nama menopause itu spesifik, tapi transisi menopause membutuhkan periode yang cukup lama. Oleh karena ini, menopause terbagi-bagi dari 4 tahap, (Zulkarnaen, 2003; Stewart, 2005; The Society of Obstetricians and Gynaecologists of Canada, 2006):

1) Premenopause adalah masa antara 40 tahun dan dimulainya siklus haid mulai tidak teratur.

2) Perimenopause adalah masa diantara premenopause dan menopause, ditandai dengan tubuh mulai berkurang dalam memproduksi hormon perempuan (estrogen dan progresterone). Rata-rata usia masa perimenopause adalah 45,1 tahun namun bisa berlangsung pada rentang usia 39 sampai 51 tahun. Masa menopause adalah 2-8 th (rata-rata 5 th).

3) Menopause adalah masa dimana fungsi ovarium berhenti dan seorang perempuan tidak lagi mendapatkan haid.

4) Pascamenopause adalah waktu ketika perempuan telah mencapai menopause, tepatnya 12 bulan setelah menopause. Ini ditandai dengan kadar LH dan FSH yang tinggi serta kadar estrogen dan progesterone yang rendah. Saat mengalami masa pasca 
menopause, perempuan akan mengalami isu kesehatan jangka panjang, misalnya osteoporosis dan gangguan kardiovaskular. Oleh karena itu, ketika mencapai menopause, adalah masa tepat bagi perempuan untuk memeriksa kesehatan secara keseluruhan dan pilihan hidup yang bisa mengatasi masalah kesehatan jangka panjang.

Tahapan-tahapan diatas menunjukkan bahwa menopause merupakan perubahan hormonal dan fisikal yang alamiah pada perempuan, namun dampak psikologis dan pengaruh budaya sangat berperan dalam pengalaman menopause perempuan.
Pengalaman menopause bersifat individual, artinya tidak semua perempuan mengalami gejala dan perubahan fisik yang sama. Kombinasi antara kesehatan (gaya hidup, genetik, pola makan, dan olahraga) dan faktor sosial (dukungan keluarga, peran ibu, pandangan masyarakat tentang menopause, terpaan media, dan faktor sosial lain) memberi kontribusi signifikan terhadap pengalaman menopause seorang perempuan.

Berikut ini adalah Tabel 1. yang menggambarkan gejala-gejala fisik, perubahan fisik dan dampakdampak psikologis yang terjadi pada setiap tahap menopause.

Tabel 1. Gejala-gejala dan Perubahan Fisik di Masa Menopause

\begin{tabular}{|c|c|c|}
\hline Tahap & Gejala/Perubahan Fisik & Gejala/Perubahan Psikologis \\
\hline Pramenopause & $\begin{array}{l}\text { - } \text { Menstruasi mulai tidak beraturan } \\
\text { - } \text { Gejala-gejala menopause kadang-kadang } \\
\text { terjadi atau bahkan tidak ada sama sekali }\end{array}$ & - Belum tampak \\
\hline Perimenopause & 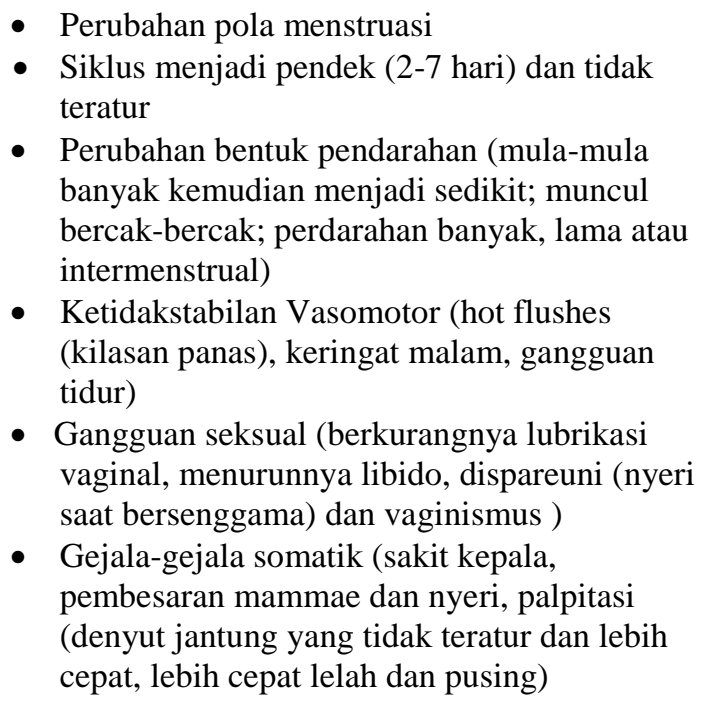 & $\begin{array}{l}\text { - Gangguan psikologis/kognitif } \\
\text { - Depresi } \\
\text { - Irritabilitas } \\
\text { - Perubahan Mood } \\
\text { - Cemas (anxiety) } \\
\text { - Kurang konsentrasi, pelupa }\end{array}$ \\
\hline Menopause & $\begin{array}{l}\text { - Menstruasi berhenti } \\
\text { - Mulai ada keluhan nyeri sendi dan sakit } \\
\text { punggung } \\
\text { - Beberapa gejala pada periode perimenopause } \\
\text { masih muncul } \\
\text { - Elastisitas kulit mulai berkurang dan muncul } \\
\text { keriput }\end{array}$ & $\begin{array}{l}\text { - Gejala sama seperti pada periode } \\
\text { perimenopause }\end{array}$ \\
\hline Pascamenopause & $\begin{array}{l}\text { - Beberapa gejala pada masa perimenopuase } \\
\text { dan menopause masih berlanjut, misalnya } \\
\text { nyeri sendi, gangguan seksual, dan } \\
\text { berkurangnya kolagen pada kulit. } \\
\text { - Osteoporosis } \\
\text { - } \text { Berat badan mudah naik } \\
\text { - Vagina berkurang kekuatan, diameter dan } \\
\text { - } \text { elastisitas } \\
\text { - Payudara mengendur }\end{array}$ & $\begin{array}{l}\text { - Mood yang gampang berubah } \\
\text { - Tetapi tingkat kecemasan dan depresi } \\
\text { menurun dibandingkan masa } \\
\text { perimenopause } \\
\text { - } \begin{array}{l}\text { Daya ingat dan kosentrasi mulai } \\
\text { menurun }\end{array}\end{array}$ \\
\hline
\end{tabular}




\subsection{Citra Tubuh}

Disadari atau tidak, citra tubuh berperan dalam kehidupan seseorang. Tidak hanya berpengaruh terhadap emosi, pikiran dan perilaku individu, tetapi citra tubuh-pun berdampak besar dalam hubungan sosial (Cash \& Pruzinsky, 2002). Misalnya mereka yang bertubuh menarik (attractive body) berkesempatan lebih besar untuk berkencan dan mendapatkan jodoh. Ini berlaku bagi laki-laki dan perempuan yang memiliki kecenderungan lebih kepada perempuan (Jackson, 2002).

Istilah citra tubuh sendiri telah digunakan dibeberapa bidang: psikologi, psikiatri, psikoanalisis, kedokteran, filosofi dan budaya, dan kajian wanita, dan juga media. Hanya saja, belum kesepakatan yang pasti mengenai definisi citra tubuh di bidang-bidang tersebut. Kajian psikologis tentang citra tubuh dari pra-1990 sampai ke dekade 1990-an dst tidak disepakati definisi tunggal mengenai citra tubuh. Pada perkembangannya, istilah citra tubuh kadang digunakan secara bergantian dengan beberapa istilah lain (skema tubuh, gangguan citra-tubuh, ketidakpuasan terhadap citra-tubuh, kepuasan terhadap penampilan, body-esteem, body-dysphorian bodyattractiveness), dsb

Ketidaksepakatan definisi ini disebabkan oleh banyaknya dimensi yang terkait yang membentuk citra tubuh. Seperti yang dinyatakan oleh Cash dkk. (dlm Baker \& Gringart, 2009), Citra tubuh adalah:

\section{A-multidimensional construct encompassing self perceptions and attitudes regarding one's physical appearance. (Suatu konstruk multidimensi yang meliputi persepsi diri dan sikap terhadap penampilan fisik seseorang).}

Lebih lanjut lagi, Tiggemann \& Lynch (2001) mengemukakan bahwa walaupun citra tubuh merupakan konstruk yang meliputi aspek perseptual, afektif dan kognitif dari pengalaman tubuh, tetapi fokus utama kajian kontemporer lebih kepada bentuk dan bobot tubuh. Ini serupa yang dikemukakan oleh Thompson (1990) yang mana citra tubuh adalah penilaian atas ukuran, berat tubuh dan aspek-aspek tubuh lainnya yang tentukan tampilan fisik seseorang.

Berdasarkan definisi-definisi di atas, maka peneliti menyimpulkan bahwa citra tubuh merupakan kontruksi multidimensi yang meliputi aspek perseptual, kognitif, afektif dan perilaku terhadap tubuh seseorang. Peneliti tidak membatasi pada bentuk, ukuran dan berat tubuh saja, tetapi juga mencakup aspek tubuh lainnya, misalnya fungsi tubuh (terkait dengan isu reproduksi dan seksualitas).

Citra tubuh seseorang tidak terjadi dengan sendirinya, tetapi ada banyak faktor yang membentuknya. Beberapa faktor yang pengaruhi pembentukan citra tubuh seseorang adalah:

1) Indeks Berat Tubuh (Body Mass Index). Indeks massa tubuh atau berat badan yang seseorang berpengaruh pada citra tubuh, terutama ketika berbicara tentang body esteem (penghargaan atas tubuh).

2) Orang tua, reaksi orang tua (memuji atau merendahkan) kepada anak secara verbal, nonverbal, atau sentuhan, dapat berkontribusi pada perkembangan citra tubuh anak. Bahkan, anakanak akan menginternalisasi bagaimana ia "diterima atau ditolak" oleh orang tua karena tubuhnya hingga bertahun-tahun lamanya (Kearney-Cooke, 2002).

3) Hubungan Interpersonal. Proses interpersonal berperan penting dalam pembentukan citra tubuh adalah penilaian yg direfleksikan (reflected appraisal), umpan balik terhadap penampilan fisik, dan perbandingan sosial. Artinya, kita merefleksikan penilaian orang lain terhadap kita karena kita merasa penting akan pendapat mereka. Sedangkan melalui umpan balik terhadap penampilan fisik, kita membangun persepsi tentang bagaimana orang lain memandang kita. Umpan balik dapat berasal dari orangtua, kakak-adik, teman sebaya, pasangan, rekan kerja, atau bahkan orang yang asing sama sekali. Faktor Terakhir adalah perbandingan sosial, yaitu proses yang juga dapat membentuk penilaian diri seseorang terhadap tubuhnya.

4) Budaya. Dalam kajian psikologis gender, ada dua teori yang digunakan dalam mengkaji konstruksi sosial budaya pada citra tubuh perempuan yaitu Objectified Body Consciousness (Kesadaran Tubuh Yang Diobjektifikasikan) dan Teori Objektifikasi. Objectified Body Consciousness atau OBC berdasarkan pada teori bahwa konstruksi budaya meletakkan perempuan sebagai objek yang dinilai dan hal ini mendorong perempuan untuk melihat tubuhnya sendiri sebagai objek, seolah-olah ada pengamat luar bagi tubuhnya (body surveillance) (McKinley dan Hyde, 1996). Menurut teori OBC, sejak dini 
perempuan telah mengalami objektifikasi seksual dari pihak lain, entah itu masyarakat ataupun media. Objektifikasi ini menjadi standar budaya yang menginternalisasi ke dalam diri perempuan. Saat perempuan mulai berfokus pada tubuhnya dan menghadapi bahwa tubuhnya tidak sesuai dengan standar budaya, maka ia akan mengalami rasa malu (body shame). Di lain pihak, ketika perempuan meyakini bahwa dirinya bisa mengontrol penampilannya (apperance control belief) maka akan lebih mudah baginya menghadapi tekanan-tekanan budaya tentang standar tubuh yang ideal. Ketiga konsep ini (body surveillance, body shame dan appearance control belief) merupakan komponen dalam teori OBC. Dalam penelitian yang dilakukan Sinclair (2006), perempuan yang menunjukkan OBC tinggi akan memiliki pengalaman tubuh yang negatif dan kesejahteraan psikologis yang rendah. Teori OBC dpt digunakan untuk mencari tahu sejauh mana perempuan yang menopause mengalami body shame atau sebaliknya memiliki kendali atas penampilan setelah memasuki masa menopause. Komponen body surveillance dikaji lebih lanjut oleh Frederickson dan Roberts dalam teori Objectification. Teori ini menjelaskan, tubuh perempuan lebih banyak dijadikan target diobjektifikasian seksual. Dalam pandangan teori ini, perempuan jika diobjektifikasikan secara seksual oleh orang lain sepanjang waktu, maka besar kemungkinan hal ini menginternalisasikan perspektif tentang dirinya menurut cara pandang orang dan lingkungan yang mengamatinya. Lebih khusus lagi dikatakan perempuan dalam usia produktif adalah target paling besar untuk diobjektifikasi. Frederickson dan Roberts (1997) mengemukakan bahwa ada tiga arena terjadi pengobjektifikasian pada perempuan. Arena pertama adalah di dalam pertemuan antar perorangan pada ruang publik. Misal, perempuan lebih besar menerima tatapan atau pandangan laki-laki yang diiringi komentar menilai yang berbau seksual. Arena kedua adalah melalui media visual yang lebih banyak menampilkan gambar "laki-laki memandang langsung ke perempuan ketimbang sebaliknya." Pengobjektifan diri (self- objectify) ini menjadi dampak yang luar biasa pada individu, yang mana perhatian perempuan sering terganggu oleh gambaran-gambaran (images) bagaimana dirinya berpenampilan munculkan kesadaran diri yang ditandai oleh seringnya memonitor tampilan tubuhnya. Seringnya individu memonitor tubuhnya atau pengobjektifikasian diri ini banyak perempuan mengembangkan identitasnya atau nilai dirinya (self-worth) berasal dari pengobjektifikasian yang didefinisikan pada penampilan fisik (Frederickson dan Roberts, 1997).

\section{METODE PENELITIAN}

\subsection{Jenis Penelitian}

Penelitian ini menggunakan pendekatan kualitatif, pendekatan yang bertujuan mempelajari permasalahan spesifik sehingga seorang peneliti dapat mengkhususkan diri pada aspek tertentu dari perilaku atau pengalaman psikologis subyek (Banister dalam Poerwandari, 1998). Seperti dikemukakan pada bab sebelumnya, penelitian berupaya mendapatkan gambaran pengalaman perempuan trhadap menopause dan bagaimana konteks sosial-budaya membentuk pengalaman ini. Oleh karenanya, pendekatan kualitatif dapat digunakan apabila peneliti ingin mengungkapkan konstruksi sosial budaya terhadap suatu realitas, dalam hal ini menopause. (Vanderstoep \& Johnston, 2009).

\subsection{Partisipan Penelitian}

Kriteria yang digunakan dalam memilih partisipan penelitian adalah perempuan yang berada di Jakarta Selatan, dan berada dalam rentang usia pramenopause dan menopause. Ini artinya rentang usia subyek adalah dari 40-65 tahun. Sebagaimana umumnya pemilihan partisipan dalam metode focus group discussion (Hennink, 2007), penelitian ini menggunakan metode purposif dan kemudian snowball. Awalnya, peneliti merekrut beberapa responden yang sesuai dengan kriteria yang telah ditentukan, Sepuluh partisipan perempuan terpilih untuk terlibat dalam penelitian ini dengan rentang usia 43-65 tahun, dengan sebaran pada tabel 2 .

Berdasarkan gambaran karakteristik pada tabel 2, maka partisipan dalam penelitian ini sebagian besar berpendidikan tinggi, minimal S1 $(80 \%)$ dan saat ini memiliki pekerjaan atau usaha $(80 \%)$. Selain itu, semua partisipan memiliki kegiatan di luar rumah (kuliah, kegiatan sosial, pengajian dan mengikuti organisasi masyarakat lainnya). 
Tabel 2. Karakteristik Partisipan

\begin{tabular}{lc}
\hline Karakteristik & Jumlah \\
\hline Usia & 5 \\
$40-45$ & 2 \\
$45-50$ & 2 \\
$50-55$ & 1 \\
$55-65$ & \\
Pendidikan & - \\
SLTA & - \\
S1 & 8 \\
S2 & 2 \\
S3 & \\
Pekerjaan & 2 \\
Tidak bekerja & 3 \\
Dosen & - \\
Karyawan & 5 \\
Wiraswasta & \\
Kegiatan di luar rumah selain pekerjaan/karir \\
Ada & 10 \\
Tidak Ada & 0 \\
\hline
\end{tabular}

Data pada tabel 3 menunjukkan bahwa 3 subyek sudah mengalami menopause, sedangkan 7 subyek belum mengalami menopause. Namun 3 dari 7 subyek telah menunjukkan segelintir gejala yang muncul dalam perimenopause. Ini bukan berarti mereka akan memasuki usia menopause dalam waktu dekat, karena gejala-gejala tersebut memang bisa muncul 5-10 tahun sebelum menopause datang.

Tabel 3. Identitas Subyek dan Status Menopause

\begin{tabular}{ccc}
\hline Inisial & Usia & Status menopause \\
\hline S1 & 43 & Belum, tapi sudah merasakan hot flushes \\
S2 & 44 & Belum, tapi sudah merasakan hot flushes \\
S3 & 43 & Belum \\
S4 & 65 & Sudah \\
S5 & 52 & Sudah \\
S6 & 55 & Sudah \\
S7 & 47 & Belum \\
S8 & 46 & Belum, tapi menstruasi tidak teratur \\
S9 & 44 & Belum \\
S10 & 43 & Belum \\
\hline
\end{tabular}

\subsection{Metode Pengumpulan Data}

Penelitian ini mengumpulkan data dengan menggunakan metode Focus Group Discussion. Metode FGD adalah suatu diskusi yang melibatkan sejumlah orang, umumnya 6 sampai 10 orang, dengan memfokuskan pada topik atau serangkaian isu tertentu. Diskusi ini memerlukan panduan dalam mengembangkan isu yang diangkat. Diskusi bisa dilakukan lebih dari satu kali. Peran peneliti adalah sebagai moderator dalam kelompok diskusi. Berbeda dengan proses wawancara, FGD membuka kesempatan untuk pesertanya saling berinteraksi. Melalui FGD, peneliti mengharapkan dapat menggali lebih banyak mengenai pandangan perempuan terhadap menopause, pengalaman menopause mereka dan bagaimana menopause membentuk citra tubuh mereka sekarang. Data FGD dikumpukan dengan cara direkam dan dicatat, kemudian ditranskrip lalu dianalisa. Proses pengolahan data ini disebut analisa isi (content analysis) (Silverman (ed), 2006).

\section{HASIL DAN PEMBAHASAN}

\subsection{Hasil}

\subsubsection{Persepsi Terhadap Menopause}

Dalam memandang menopause, seluruh subyek sepakat, menopause merupakan pengalaman alamiah yang harus dihadapi oleh perempuan. Bagi para subyek yang belum mengalaminya, mereka menyatakan bahwa menopause merupakan kejadian alamiah, kodrat seorang perempuan dan bagian dari fase kehidupan. Beberapa ungkapan mereka, misalnya:

\section{"Menopause memang sudah kodrat wanita, sudah dari sananya begitu, ga usah dipikirin." \\ "Saya belum menjalankannya, tapi saya ya merasa biasa-biasa saja. Kalau harus dihadapi, ya hadapi saja. Tidak harus bagaimana-bagaimana."}

\section{"Saya memahami itu (menopause) sebagai kejadian alami saja."}

Ketika digali lebih lanjut mengenai sejauh mereka memahami menopause, seluruh subyek menyatakan bahwa menopause adalah berhentinya menstruasi. Namun sebagian subyek (empat dari tujuh subyek) dapat mengidentifikasi bahwa menopause diikuti dengan beberapa gejala dan perubahan tertentu. Umumnya, para subyek kenali perubahan hormonal, emosi, hot flashes dan kecenderungan untuk mengalami osteoporosis sebagai pertanda menopause. Subyek sepuluh misalnya mengatakan: 
"Ada juga perubahan hormonal, yang mungkin juga menimbulkan perubahan emosi, dan risiko-risiko penyakit yang mungkin meningkat."

Tetapi ada sebagian dari subyek mendapatkan informasi dari orang lain bahwa menopause mengakibatkan vagina kering dan ini dihubungkan dengan gangguan dalam hubungan suami isteri atau penyebab suami selingkuh. Informasi ini yang menurut mereka dapat membuat perempuan cemas dalam menghadapi menopause. Namun, semua subyek sepakat bahwa informasi ini tidak banyak mempengaruhi mereka.

Pemahaman tentang menopause ini tentunya tidak lepas dari bagaimana mereka mendapatkan informasi tentang menopause itu sendiri. Maka, kami menanyakan bagaimana para subyek mendapatkan informasi tentang menopause. Sebagian besar subyek (7 dari 10) mengatakan bahwa ibu adalah sumber utama memperoleh informasi menopause. Contohnya, subyek dua menceritakan bahwa sejak pertama mendapatkan menstruasi, ibunya sudah memperkenalkan tentang menopause dan ciri-cirinya, misalnya panas, keringatan, kurang bernafsu dengan suami dan tubuh yang membesar. Sementara sumber lainnya adalah kerabat terdekat (kakak dan tante), dokter, teman sebaya, majalah, internet dan sekolah. Subyek tujuh mengemukakan bahwa pengalaman uwak (kakak perempuan dari pihak orang tua) ternyata mempengaruhi sikapnya. Saat melihat uwaknya bersikap biasa saja dalam menghadapi menopause, ia pun tidak mengkhawatirkan masa menopause bila terjadi padanya kelak.

Tidak hanya pendapat dan pemahaman mereka tentang menopause, kami menggali pengalaman menopause. Tiga dari tujuh subyek yang belum memasuki menopause mengemukakan bahwa mereka telah mengalami gejala-gejala yang mengindikasi menopause. Dua subyek melaporkan bahwa mereka saat ini mengalami hot flashes, dan seorang subyek mengalami mens yang tidak teratur. Tetapi ketiganya belum memastikan apakah ini termasuk gejala-gejala menopause atau tidak. Berikut adalah pernyataan subyek satu, subyek dua dan subyek delapan dalam menanggapi gejalagejala yang mereka alami:

"Kayaknya suka terasa, kayaknya suka 'tenngg'. Apa ini hot flash bukan ya? Suka bertanya-tanya gitu. Mungkin, Apalagi kalau sedang konsentrasi di komputer gitu. Terasa sekilas-sekilas saja."

"Saat ini sering merasakan panas di pipi, kadang keringatan... tapi aku sih emang dari dulu keringatan. Ga tahu juga ini efek dari mau masuk masa menopause atau bukan..."

"Mens saya tidak teratur, tapi (gejala) lainnya ga ada apa-apa. Kata dokter belum masanya menopause. Masih lama, mungkin ada masalah. Tapi ga tau ya..."

Dua subyek pertama tidak melakukan tindak lanjut terhadap gejala-gejala yang mereka hadapi, namun subyek ketiga berkonsultasi kepada dokter untuk mendapatkan penanganan lebih lanjut.

Untuk mendapatkan informasi mengenai kehidupan pada masa menopause dan setelah menopause, kami menggali pandangan dan pengalaman tiga subyek yang sudah melewati masa menopause. Kami menemukan bahwa ketiga subyek memiliki pandangan yang hampir sama dengan subyeksubyek yang belum menopause. Ketiga subyek melihat bahwa menopause adalah hal yang harus dihadapi dan bukan menjadi akhir dari kehidupan. Misalnya, subyek enam mengungkapkan:

\section{"Kalau saya menganggap bahwa manusia mengalami fase itu. Kita siapkan diri saja untuk memasuki masa itu (menopause)... Kalau ada masalah bisa konsultasi ke dokter kandungan. Tapi sejauh ini sih nggak (ada masalah)..."}

Saat bahas mengenai pengalaman menopause, ketiga subyek memiliki pengalaman yang berbeda. Subyek empat melaporkan bahwa ia hanya mengalami perubahan sikluas menstruasi saja. Awalnya, periode menstruasinya sekitar 4-5 hari, tapi kemudian berangsur-angsur berkurang dan berhenti sekali. Mengenai perubahan suasana hati (mood) dan hot flashes, subyek tidak merasakan mengalami keduanya.

Sebaliknya, subyek lima sampaikan bahwa ia mengalami ketidaknyamanan fisik dan psikologis selama setahun sebelum memasuki masa menopause. Secara fisik, ia merasa gerah, cepat lelah, tubuh sering tidak nyaman dan kurang tidur. Selain itu siklus menstruasi berubah, kadang terusmenerus melebihi waktu biasanya (bisa sampai tiga minggu) dan dalam jumlah yang banyak. Secara emosional, subyek tiga mengaku sering gelisah dan 
kondisi emosinya naik turun, terutama pada malam hari. Dalam menghadapi ketidaknyamanan ini, subyek lima mengaku kesibukannya membantunya mengatasi ketidaknyamanan ini. Selain itu peran keluarga dan teman-teman dalam memberikan dukungan sangat besar. Ia menceritakan:

"Saya kan punya banyak kegiatan, jadi ya tidak terlalu dipikirkan... Juga, saya kan sering ngobrol dengan teman-teman... saling share lah, jadi saya dapat banyak masukan, informasi dari pengalaman teman-teman."

Sementara itu, subyek enam menceritakan bahwa sekitar usia 47 tahun, ia mulai merasakan hot flashes, khususnya di pagi hari dan hanya pada wajah bagian kanan. Tetapi, masa menopausenya sendiri terjadi lebih dini, karena ada pengangkatan miom di usia 47 tahun. Seperti yang diungkapkannya:

\section{"Menstruasi saya masih bagus sampai akhirnya saya harus operasi karena ada miom dan diangkat indung telur. Jadi agak dipaksakan untuk menopause. Menurut dokter saya, kalau melihat sejarah saya, seharusnya saya belum menopause."}

Tidak hanya sebatas pengalaman menopause, subyek yang sudah mengalami menopause pun kami minta untuk menceritakan bagaimana kehidupan mereka setelah mengalami menopause. Menurut subyek empat, kehidupan setelah memasuki menopause lebih dari lima belas tahun tidak banyak perubahan. Ia masih beraktivitas seperti biasa, mengikuti pengajian rutin, berwiraswasta bahkan berkuliah kembali. Setelah menopause, subyek merasa bahwa beribadah justru lebih mudah karena tidak "terganggu" oleh menstruasi. Puasa dapat dijalankan sepenuhnya, tanpa harus mengganti waktu lain. Subyek percaya bahwa masa paska-menopause dapat diatasi apabila individu mempersiapkan diri menghadapi masa menopause. Ia menekankan pada pentingnya seorang perempuan untuk mencari informasi terkait dengan menopause, tetapi sekaligus dapat menyaringnya sehingga tidak menelan mitos-mitos yang melingkupi menopause. Subyek empat mengatakan:

"Jadi untuk menghadapi menopause itu, kita harus siap mental. Yang kata orang begini atau begitu (maksudnya efek buruk setelah menopause-red), nyatanya tidak terbukti... Pengaruh orang ngomong, menopause itu kayak kiamat bagi perempuan memang ada ya, tapi tidak lalu mentah ditelan."

Subyek lima telah menjalani lima tahun kehidupan paska menopause. Menurutnya, setelah memasuki masa menopause, ia merasa lebih tenang, baik secara fisik dan psikologis. Ia juga merasakan selera makannya membaik. Perubahan yang paling dirasakan adalah tubuhnya mudah membesar, tapi ia tidak mempermasalahkan hal tersebut. Selain itu, subyek lima menikah setelah mengalami menopause. Seperti juga halnya subyek empat, subyek lima merasa kalau setelah menopause, ibadahnya justru lebih lancar, tidak terhenti karena menstruasi atau direpotkan dengan urusan menstruasi setiap bulannya.

Terakhir adalah subyek enam, yang telah menjalani masa menopause sekitar 8 tahun. Subyek mengakui bahwa ia menikmati kehidupannya setelah menopause. Menurutnya, tidak ada gangguan fisik dan emosional berarti yang dialaminya sejak mengalami menopause. Mengenai jam tidur yang berkurang misalnya, ia menanggapi:

"Jam tidur berkurang? eehh kalau saya memang penikmat saat-saat tenang, jadi kalau semua sudah tidur, otak saya rada-rada berkembang nih... bagi saya, tidur di atas jam 12 bukan jam tidur berkurang. Dinikmati aja gitu."

Pernah sesekali ia mendadak mengalami kesedihan tanpa sebab, tapi setelah mengkonsumsi Primrose, emosinya menjadi stabil kembali. Subyek mengakui mind set (pola pikir) yang positif tentang menopause sangat membantunya dalam menghadapi masa menopause.

Dari ketiga subyek di atas, penelitian ini menemukan bahwasannya keyakinan terhadap nilai-nilai agama mempengaruhi bagaimana subyek menjalankan kehidupan setelah menopause. Subyek enam, misalnya, menuturkan:

"Buat saya, agama sangat-sangat penting.
Menopause kan datangnya dari Allah, seperti
juga menstruasi. Agama juga sangat penting
buat menenangkan orang. Alangkah baiknya
kalau wanita merasa bermasalah karena
menopause bisa menenangkan ke agama atau
(pergi) ke ustadz yang menerangkan kalau
menopause adalah bagian dari siklus
kehidupan." 
Berdasarkan wawancara dengan para subyek mengenai persepsi terhadap menopause, disimpulkan bahwa semua subyek, baik yang belum, menjelang, dan menjalani masa menopause, memandang bahwa menopause adalah sesuatu yang alamiah dan kodrati. Sebagian subyek juga melatari persepsi mereka dengan ajaran agama. Dibandingkan subyek yang sudah menopause, pengetahuan subyek yang belum mengalami menopause masih terbatas. Umumnya, sumber informasi yang mereka dapatkan adalah ibu, kerabat, teman-teman dan dokter. Mengenai pengalaman menopause, sebagian besar subyek mengakui mengalami hot flashes atau kilasan panas. Tetapi ada juga subyek yang tidak mengalami apa-apa pada saat menjelang menopause. Menariknya, religiusitas menjadi aspek penting dalam membentuk persepsi tentang menopause dan pengalaman menopause.

\subsubsection{Citra Tubuh Menopause}

Masa menopause sering dihubungkan dengan perubahan fisik. Tidak hanya bentuk tubuh yang berubah, tetapi elastisitas kulit pun mulai berkurang (misalnya, keriput di bagian wajah). Tidak heran apabila menopause diasosiasikan dengan tua. Dalam penelitian ini, ketujuh subyek yang belum mengalami menopause menyadari bahwa ketika menopause, akan terjadi perubahan fisik, seperti: tubuh yang tidak lagi muda (subyek satu, subyek tiga dan subyek tujuh, subyek delapan, dan subyek sembilan), tidak lagi sekuat dulu, misalnya lutut lebih mudah sakit (subyek sepuluh) dan tubuh yang menua atau aging (subyek dua). Sebelum masuk ke dalam pandangan mereka terhadap tubuh menopause, subyek-subyek ini diminta untuk menjawab pertanyaan tentang sejauh mana mereka menggangap penampilan fisik (dalam hal ini tubuh) penting. Hanya tiga dari tujuh subyek (subyek satu, subyek delapan dan subyek sembilan) menjawab bahwa penampilan fisik termasuk hal yang penting, tetapi mereka mengutamakan pada kebugaran dan kesehatan. Pendapat yang terakhir ini juga disepakati oleh subyek-subyek lainnya. Seperti yang dinyatakan oleh subyek satu:

\section{"Sebetulnya yang lebih penting adalah badan segar, tidak kena penyakit dan tidak gampang flu. Nah itu bisa tercapai kalau kita fit badannya, misalnya dengan banyak bergerak sama makanan yang bagus, ga terlalu banyak dan sehat."}

Dalam merawat dan menjaga kesehatan tubuh, masing-masing subyek memiliki cara yang berbeda.
Subyek pertama, tidak melakukan olahraga rutin namun ia menjaga pola makan dan melakukan perawatan wajah yang sederhana.

\section{"Olahraga rutin khusus, nggak. Pagi-pagi beres-beres aja, nyapu, ngepel. Itu juga sudah basah kuyup. Makan juga dikurangi. Perawatan wajah juga yang santai saja, kayak pakai pelembab, pakai masker. Tapi khusus ke salon, facelift atau botox lah. “}

Subyek dua merawat tubuh dengan cara alternatif, seperti totok. Subyek tiga, melakukan lari dan renang secara rutin. Ia melakukan kedua olahraga tersebut tidak hanya karena menjaga kebugaran, tetapi juga karena memiliki masalah tulang belakang. Subyek tujuh menjaga kebugaran dengan mengikuti aerobik setiap sabtu, menjaga makanan dan lebih banyak mengkonsumsi buah-buahan. Subyek delapan melakukan fitness rutin dan menjaga porsi makanan (tidak banyak tetapi juga tidak terlalu sedikit). Subyek sembilan tidak berolahraga, tetapi melakukan perawatan misalnya facial. Sementara subyek sepuluh menjaga tubuh dengan berolah raga bela diri. Ketika ditanyakan lebih lanjut apakah ada kekhawatiran terhadap perubahan fisik pada saat menopause nanti, enam dari tujuh subyek (86\%) tidak merasa khawatir terhadap perubahan fisik yang akan mereka hadapi. Subyek dua, misalnya, mengungkapkan:

\section{"Sudahlah, terima saja, kan sudah kodratnya, Mau diapain pun, sampai suntik segala, buat apa?Menghabiskan duit, toh diapain juga masa itu tetap datang"}

Berbeda dengan subyek-subyek lainnya, subyek sembilan mengungkapkan kekhawatirannya tentang tubuh menopause:

"Itu yang saya khawatirkan ketika orang berbicara tentang menopause, apalagi saat tubuh menjadi gemuk."

Pandangan ketujuh subyek terhadap tubuh menopause dipengaruhi oleh orang-orang terdekat mereka. Sosok perempuan lebih tua di lingkungan keluarga terdekat memiliki pengaruh yang cukup penting bagi beberapa subyek. Subyek tujuh merujuk kepada pengalaman menopause para uwaknya (kakak perempuan dari orangtua) dan lima subyek (subyek satu, subyek dua, subyek tiga, subyek delapan dan subyek sepuluh) mengatakan bahwa ibu berperan membentuk pandangan mereka 
tentang tubuh menopause. Sebagai contoh, subyek tiga menguraikan:

"Kalau saya, mungkin saya lihat ibu saya ya. Saya merasa kok ibu ga aneh-aneh, seperti itu, biasa saja. Jadi saya biasa saja."

Subyek dua memiliki kesamaan pendapat:

"Aku sih lebih percaya pada pengalaman dan kata-kata ibuku. Sebagian teman memang ada yang melakukan perawatan memasuki masa menopause, tapi kalo aku sih ga lah..."

Teman-teman, meskipun diakui oleh para subyek menjadi salah satu sumber informasi mereka mengenai menopause, namun pengaruhnya tidak terlalu dominan dalam membentuk pandangan ketujuh subyek terhadap tubuh secara umum. Subyek satu, misalnya, memberikan pendapatnya ketika ditanyakan apakah komentar temantemannya tentang tubuh dan penampilan berpengaruh terhadapnya:

"Kalau komentar teman positif ya ngaruh, tapi kalau dibilang gendut ya ga peduli... Kalau komentarnya ada basic pengetahuan, ga harus ilmiah ya, ya bisa diterima. Kalau mitos yang kita nggak tahu akibatnya, ya ga lah... Saya orangnya memang tidak tergantung pada perkataan teman ya."

Senada dengan subyek satu, subyek tiga menjawab:

"Temen-temen saya saja kurus-kurus semua, tapi saya ga. Ga ada pengaruh nya buat saya..."

Selanjutnya, kami memfokuskan kepada pengalaman tubuh (menopausal body) dari subyeksubyek yang telah mengalami menopause dan apakah perubahan fisik berpengaruh terhadap hubungan dengan pasangan. Subyek empat mengatakan bahwa ukuran tubuhnya tidak berubah semenjak memasuki usia menopause. Tetapi untuk menjaga agar tetap bugar, subyek mengatur pola makan. Selain itu, ia mengikuti senam dan kursus dansa bersama suaminya. Menurut subyek, kursus dansa ini tidak hanya berfungsi untuk menjaga kesehatan dan melatih daya ingat, tetapi juga menjadi alat untuk menciptakan kebersamaan dengan suaminya. Hubungan suami isteri tidak lagi dihubungkan dengan kegiatan seksual semata, tetapi juga membangun kebersamaan melalui aktivitas kesenangan-kesenangan yang dilakukan bersama pasangan. Berikut penuturannya:

"Jadi saya ikut dansa berdua dengan suami. Olahraga yang penting berdua dengan suami.. Pokoknya kesenangan-kesenangan yang tidak hanya dengan kegiatan yang dilakukan di tempat tidur..Ternyata dengan dansa itu memang kebersamaan terbangun".

Subyek lima dan subyek enam memiliki pengalaman tubuh yang berbeda dengan subyek sebelumnya. Mereka mengakui bahwa tubuh mereka membesar setelah memasuki usia menopause, tetapi subyek enam secara khusus mengatakan bahwa ia termasuk emotional eater. Artinya, tubuhnya gemuk bukan karena menopause, tetapi karena menjadikan makanan sebagai pelarian ketika ada masalah. Walaupun demikian, subyek enam berolahraga secara rutin dan mengikuti dansa. Bagi kedua subyek, membesarnya tubuh tidak menjadi kekhawatiran. Bagi subyek lima, misalnya, penerimaan suami terhadap tubuhnya setelah menopause membuat ia tidak merisaukan berat badannya. Baginya, sehat dan kebahagiaan lebih penting daripada berat tubuh.

Berbicara mengenai citra tubuh perempuan menopause, bentuk dan ukuran tubuh bukanlah satu-satunya isu. Kegiatan seksual pun menjadi perhatian penting. Hubungan seksual yang dapat terganggu akibatnya berkurangnya cairan vagina telah menjadi momok yang menakutkan baik di kalangan perempuan yang belum atau yang menjelang menopause. Ketakutan ini dapat berpengaruh terhadap bagaimana mereka memandang tubuhnya. Dalam wawancara, ketiga subyek mengatakan bahwa mereka masih berhubungan seksual secara aktif dan tidak terganggu karena menopause. Sebagai contoh, subyek enam mengemukakan:

\footnotetext{
"Sebenarnya kalau kita menurut saya kalau kita enjoy.. bagi saya, kalau kita melakukannya secara enjoy, istilahnya kalau hubungan itu dinikmati, otomatis semuanya jalannya biasa aja sih. Begitu kita khawatir, kering... begitu kering timbul deh masalah... merasa sakit, kemudian merasa ga lancar... merasa ga berguna...”
}

Ketiga subyek sepakat bahwa peran suami dalam menerima kondisi menopause membuat mereka tidak khawatir terhadap perubahan fisik yang 
terjadi saat menopause. Selain peran suami, peran ibu juga penting dalam membentuk citra tubuh menopause (subyek tiga dan subyek lima) dan bahkan memberikan gambaran terhadap hubungan pasangan selama usia menopause. Subyek tiga, misalnya, belajar dari pengalaman ibunya saat menopause. Menurutnya, ibunya tidak memiliki menunjukkan kecemasan pada bentuk tubuhnya saat menopause dan masih memperlihatkan kemesraan dengan ayahnya di usia tua mereka.

Dibandingkan ibu, teman-teman tidak memiliki pengaruh yang kuat terhadap pembentukan citra tubuh ketiga subyek. Teman-teman lebih banyak mengambil peran sumber informasi dan berbagai pengalaman. Subyek lima menceritakan:

"Saya kan sering ngobrol dengan tementemen.. saling share lah ya... Ada yang kayak saya, ada yang takut melar... Jadi saya tuh dapat banyak masukan, informasi lah ya, dari pengalaman teman2"

Dari uraian di atas mengenai citra tubuh menopause, dapat disimpulkan bahwa sebagian subyek menganggap penampilan fisik dan tubuh adalah penting, namun seluruh subyek sepakat untuk menekankan pentingnya kebugaran dan kesehatan tubuh. Ini dibuktikan dengan para subyek melakukan olahraga dan memperhatikan pola makannya. Beberapa subyek pun melakukan perawatan wajah.

Bagi para subyek yang belum mengalami menopause, mereka memandang tubuh menopause sebagai tanda-tanda penuaan, tetapi pandangan mereka ini tidak diikuti dengan kekhawatiran dan ketakutan yang berlebihan. Hal ini terjadi karena adanya pengaruh dari sosok ibu atau perempuan yang lebih tua dari keluarga. Oleh karena itu, meskipun lingkungan teman memberikan informasi yang "negatif" mengenai tubuh menopause, sebagian besar subyek tidak membiarkan informasi ini membentuk pandangan mereka tentang tubuh menopause. Bagi tiga orang subyek yang sudah memasuki usia menopause, kesehatan lebih diutamakan dari sekedar penampilan fisik. Pandangan dan sikap suami terhadap tubuh mereka juga berperan. Penerimaan suami terhadap tubuh menopause membuat mereka tidak terlalu khawatir terhadap perubahan fisik yang mereka alami. Sebagian subyek merujuk kepada pengalaman ibu dalam menjalani pengalaman menopause, bahkan ketika lingkungan sekitar memberikan informasi yang negatif terhadap perubahan fisik tubuh menopause dan konsekuensinya terhadap pasangan.

\subsection{Diskusi}

Hasil wawancara dengan sepuluh subyek memperlihatkan bahwa mereka memiliki persepsi yang sama mengenai menopause, yaitu menopause adalah hal yang alamiah dan kodrati bagi perempuan. Oleh karena itu, menopause bukanlah sesuatu yang perlu ditakutkan. Ini berbeda dengan penelitian-penelitian tentang menopause dari dunia Barat yang mengungkapkan bahwa menopause sebagai pengalaman negatif dan membuat cemas para perempuan (Dillaway, 2005). Walaupun tidak mengkhawatirkan bagi para subyek, tetapi menopause dihubungkan dengan adanya perubahan-perubahan fisik yang negatif. Dalam hal ini, para subyek merujuk kepada penurunan stamina yang tidak sekuat sebelumnya, bentuk tubuh yang tidak semuda dulu, kulit mengendur dan gairah terhadap pasangan yang menurun. Beberapa kondisi ini oleh beberapa subyek diasosiasikan dengan proses penuaan (age-ing).

Pada sebagian besar subyek, baik yang di usia pramenopause dan post-menopause, ketidakhawatiran mereka dalam menghadapi menopause banyak dipengaruhi oleh pengalaman menopause sang ibu. Ibu dari sebagian besar subyek menjalani kehidupan menopause yang positif (misalnya, tidak melakukan intervensi medis dalam merubah bentuk badan). Pengalaman tubuh menopause ibu yang positif berperan besar dalam membentuk persepsi positif para subyek tentang menopause. Beberapa penelitian tentang citra tubuh pun pernah menyoroti hubungan antara ibu dan anak perempuan, ditemukan bahwa ibu ternyata berperan besar dalam membentuk pandangan anak tentang tubuhnya sendiri (Kearney-Cooke, 2002).

Bagi subyek yang berada di masa paska menopause, peran pasangan adalah penting. Kami menemukan bahwa tubuh menopause subyek tidak menjadi masalah, karena adanya penerimaan dari pasangan (suami) terhadap tubuh menopause mereka. Hal ini jugalah yang membuat aktifitas seksual mereka tidak menjadi isu dalam kehidupan menopause mereka. Kepuasan seksual pun bukan lagi menjadi tujuan utama dalam hubungan suami isteri. Di usia paruh baya, hubungan suami isteri lebih ditekankan kepada kebersamaan dalam menjalani hari tua. 
Persepsi terhadap menopause dan pengalaman menopause yang positif tidak berarti para subyek tidak terpapar oleh gambaran tubuh ideal yang dikonstruksikan oleh budaya. Pernyataan seperti "tubuh yang tidak muda", "berat badan naik", "gairah seksual yang menurun" mencerminkan bahwa tubuh menopause sudah tidak sesuai dengan tubuh ideal yang dikonstruksikan oleh budaya. Informasi-informasi yang "menakutkan" tentang menopause yang didapat oleh subyek dari temantemannya menunjukkan bahwa bagi beberapa perempuan di Jakarta, tubuh menopause dipandang sebagai hal negatif dan menopause dipandangan sebagai pengalaman yang menakutkan. Bahkan pandangan menopause sebagai "kiamat" bagi perempuan dapat ditemui di kalangan perempuan Jakarta. Hanya saja, subyek-subyek dalam penelitian kami tidak memperlihatkan kecenderungan itu. Satu hal yang bisa menjelaskan ini adalah faktor religiusitas yang kami temui muncul dalam kebanyakan subyek. Para subyek melandasi pandangan dan pengalaman mereka terhadap menopause dengan ajaran agama. Di masa paska menopause, bahkan, praktik agama menjadi sandaran utama bagi subyek-subyek. Misalnya, ibadah shalat dan puasa yang lebih lancar dibandingkan masa menstruasi (saat menstruasi, perempuan tidak diperbolehkan menjalankan kedua ibadah tersebut). Hubungan religiusitas dan menopause dalam penelitian ini tidak digali lebih dalam, tetapi penemuan ini membuka ruang yang lebih lebar bagi para peneliti lain untuk mengkajinya.

Secara ringkasnya, penemuan-penemuan dalam penelitian ini mencakup:

1) Pengetahuan menopause pada sebagian besar subyek masih terbatas. Ini mengindikasikan bahwa diseminasi menopause belum merata di kalangan perempuan paruh baya. Banyaknya informasi yang keliru tentang menopause tentu bisa membentuk persepsi negatif tentang menopause dan menimbulkan ketakutan bagi sebagian perempuan.

2) Faktor keluarga terdekat, seperti Ibu dan kerabat perempuan, berperan besar dalam membentuk persepsi tentang menopause dan tubuh menopause.

3) Pasangan, dalam hal ini suami, memiliki peran besar dalam menjalani kehidupan menopause.

4) Tingkat religiusitas yang tinggi dapat membantu perempuan menghadapi menopause dan menjalani kehidupan paska menopause dengan lancar.
Karena penelitian kami bersifat kualitatif dan melibatkan sepuluh subyek saja, maka hasil penelitian ini tidak dapat digeneralisasikan. Namun demikian penemuan kami memperlihatkan bahwa menopause tidak hanya mencakup aspek biologis seorang perempuan, tetapi juga aspek psikologis, aspek sosial budaya dan aspek agama dari seorang perempuan. Oleh karena itu, kajian tentang menopause memberikan ruang luas bagi para peneliti untuk mengkajinya lebih dalam dan menghasilkan penemuan yang dapat berguna bagi kehidupan perempuan di masa paruh baya.

\section{KESIMPULAN}

Menopause adalah proses dimana perempuan berhenti menstruasi. Proses ini menimbulkan dampak biologis terhadap tubuh perempuan, salah satunya adalah berkurangnya hormon estrogen dan progesteron yang berakibat pada perubahan fisik, yang kemudian dihubungkan dengan penuaan (ageing). Karena itulah, menopause dipandang sebagai pengalaman tubuh yang negatif. Namun demikian, beberapa kajian feminis berargumen bahwa pada menopause merupakan pengalaman tubuh yang netral. Sementara, penelitian antropologis menemukan bahwa konteks sosial-budaya berperan besar terhadap sejauh mana menopause dipandang secara negatif atau positif. Pada penelitian ini, kami menemukan bahwa menopause dipersepsikan secara positif oleh subyek yang berada pada usia pra-menopause dan peri-menopause. Bagi mereka yang sudah mengalami menopause, pengalaman tubuh menopause mereka dijalani secara positif.

Beberapa responden menyatakan bahwa penerimaan positif pada menopause dipengaruhi oleh beberapa faktor, yaitu:

1) Peranan keluarga (dalam hal ini ibu) dalam mempersiapkan putrinya (responden) dalam menghadapi masa menopause

2) Adanya dukungan dari keluarga dan lingkungan sosial

3) Penerimaan suami yang tidak mempermasalahkan istri yang mengalami masa menopause dan yang telah menopause.

4) Dan yang tidak terduga ditemukan dalam penelitian adalah, faktor religiusitas memberikan kemantapan psikologis kepada para perempuan dalam menghadapi dan menerima masa menopause 


\section{DAFTAR ACUAN/PUSTAKA}

Buku dan Jurnal

[1] Berger, Gabriella E. (1999). Menopause and Culture. (London: Pluto Press)

[2] Dillaway, Heather E. (2005). (Un)Changing Menopausal Bodies: How Women Think and Act in the Face of a Reproductive Transition and Gendered Beauty Ideals. Sex Roles, Vol. 53, Nos. $1 / 2$, July 2005

[3] Davison, Tanya E. dan McCabe, Marita P. (2005). Relationships Between Men's and Women's Body Image and Their Psychological, Social, and Sexual Functioning. Sex Roles, Vol. 52, Nos. 7/8, April 2005

[4] Flint, M. dan Samil, R.S. (1990) Cultural and subcultural meanings of the menopause in Flint, M., Kronenberg, F. and Utian, W. (eds) Multidisciplinary Perspectives on Menopause (New York: New York Academy of Sciences).

[5] Furman, Sue C. (1995). Turning Point: The Myths and Realities of Menopause. (Oxford: Oxford University Press)

[6] Kartika, Yulia (2007). Citra Tubuh Ideal Perempuan Yang Berlatar Belakang Budaya Bugis dan Tinggal di Jakarta (Ditinjau dari Teori Objectified Body Consciousnee dan Teori SelfObjectification). (Depok: Tesis Program Pasca Sarjana Fakultas Psikologi Universitas Indonesia)

[7] Sievert, Lynnette Leidy (2006). Menopause: A Biocultural Perspective. (London: Rutgers University Press)
[8] Silverman, David. 2006. Qualitative Research Theory, Method and Practice Second edition. London : SAGE

[9] Stewart, Donna E. (2005) Menopause: A Mental Health Practitioner's Guide edited by Donna E. Stewart. (Virginia: American Psychiatric Publishing Inc.)

[10] The Society of Obstetricians and Gynaecologists of Canada (2006). The Journalist's Menopause Handbook: A Companion Guide to the Society of The Society of Obstetricians and Gynaecologists of Canda Menopause Consensus Report.

[11] Thompson, JK (1990). Body image disturbance: Assessment and treatment. Elmsford. (New York: Pergamon Press)

[12] Vanderstoep, Scott W. \& Johnston, Deirdre D. (2009) Research Methods for Everyday Life (San Fransisco: Jossey-Bass)

Artikel Koran dan Internet

[13] Asa, Adinda (2010). Perjalanan Nyata Industri Kecantikan. Media Indonesia, Rabu 15 Desember 2010

[14] Dechacare.com. Kiat Menghadapi Menopause. (Diakses tanggal 20 Februari 2011)

[15] Kalyanamitra.multiply.com, Bencana di Balik Mitos Kecantikan. (Diakses tanggal 20 Februari 2011)

[16] Rachmawati, Evy (2006). Menopause, Siapa Takut. http://www.kompas.co.id/kompas-cetak/ 0611/24/kesehatan/3117848.htm (Diakses tanggal 17 Februari 2011) 